\title{
ACUTE PHYSIOLOGY AND CHRONIC HEALTH EVALUATION (APACHE) II SCORE - THE CLINICAL PREDICTOR IN NEUROSURGICAL INTENSIVE CARE UNIT
}

\author{
Phuping Akavipat ${ }^{1}$, Jadsada Thinkhamrop ${ }^{2}$, Bandit Thinkhamrop ${ }^{3}$ and Wimonrat Sriraj ${ }^{4}$
}

${ }^{1}$ Anesthesiology Department, Prasat Neurological Institute, Bangkok, Thailand; ${ }^{2}$ Department of Obstetrics and Gynecology, Faculty of Medicine, Khon Kaen University, Khon Kaen, Thailand; ${ }^{3}$ Department of Biostatistics and Demography, Faculty of Public Health, Khon Kaen University, Khon Kaen, Thailand; ${ }^{4}$ Department of Anesthesiology, Faculty of Medicine, Khon Kaen University, Khon Kaen, Thailand

SUMMARY - The APACHE II scoring system is approved for its benchmarking and mortality predictions, but there are only a few articles published to demonstrate it in neurosurgical patients. Therefore, this study was performed to acknowledge this score and its predictive performance to hospital mortality in a tertiary referral neurosurgical intensive care unit (ICU). All patients admitted to the Neurosurgical ICU from February 1 to July 31, 2011 were recruited. The parameters indicated in APACHE II score were collected. The adjusted predicted risk of death was calculated and compared with the death rate observed. Descriptive statistics including the receiver operating characteristic curve (ROC) was performed. The results showed that 276 patients were admitted during the mentioned period. The APACHE II score was 16.56 (95\% CI, 15.84-17.29) and 19.08 (95\% CI, 15.4022.76 ) in survivors and non-survivors, while the adjusted predicted death rates were $13.39 \%$ ( $95 \% \mathrm{CI}$, $11.83-14.95)$ and $17.49 \%$ (95\% CI, 9.81-25.17), respectively. The observed mortality was only $4.35 \%$. The area under the ROC of APACHE II score to the hospital mortality was 0.62 (95\% CI, 0.44 0.79). In conclusion, not only the APACHE II score in neurosurgical patients indicated low severity, but its performance to predict hospital mortality was also inferior. Additional studies of predicting mortality among these critical patients should be undertaken.

Key words: APACHE; Hospital mortality; Length of stay; Severity of illness index; Intensive care units

\section{Introduction}

In the era of quality-based medicine, high-risk neurosurgical patients represent a considerable proportion of intensive care unit (ICU) admissions aiming to fulfill the gap of treatment standard and expecting the best clinical outcome. However, some recent studies showed the mortality in neurosurgical ICU to be three times higher than in general ICU, accounting

Correspondence to: Phuping Akavipat, MD, FRCAT, PhD, Anesthesiology Department, Prasat Neurological Institute, 312 Rajvithee Road, Bangkok 10400, Thailand

E-mail: ppakvp@hotmail.com

Received March 13, 2017, accepted January 23, 2019 for $22.5 \%-24.8 \%$ of the in-hospital mortality and $39.8 \%$ of the mortality after 1 year $^{1-3}$. Information derivable from effective mortality predicting tools may facilitate the appropriate administrative management rationale among the scarcity of healthcare resources and help guiding physician for proper evidence-based decision-making.

A widely used ICU prognostic scoring model, the Acute Physiology and Chronic Health Evaluation II (APACHE II) scoring system has been recognized. It has shown to be an accurate measurement of patient severity and correlates strongly with outcome in critical patients $s^{4,5}$. The highly differentiated affinity among critically ill patients was shown by the AUC of 0.806- 
$0.892^{6-9}$. The familiarity is achieved because of its less variables and no calculation converted for any sea levels affected ${ }^{4,10}$. The APACHE II score can compare and benchmark for the effectiveness, efficacy and quality matter of each unit individually ${ }^{11,12}$. Nonetheless, the qualified systematic database indicating APACHE II score, i.e. patient diagnosis, clinical condition, scientific parameters and laboratory values could hardly be established in routine ${ }^{13,14}$. Particularly in fragile neurosurgical patients, the clinical condition may alter and need specific treatment immediately.

The length of stay is one of the most concerned issues not only for the healthcare personnel but also the patients, relatives and health insurance providers ${ }^{15}$. Some literature data indicate that the mean length of ICU stay is 4.5-6.0 days for the patient undergoing craniotomy with blood clot removal, 1.8-2.9 days for the patient undergoing craniotomy without blood clot removal, and $11.2 \pm 15.4$ days for stroke patients ${ }^{16}$. However, there is still no strong evidence supporting the validity of the length of hospital stay estimators in these groups of patients.

From the critical appraisal process, few articles reviewed the value of APACHE II score and performance of mortality prediction in subspecialty ICUs that have different case-mix and different providermix such as neurosurgical ICU ${ }^{3}$. The discordance between the predictive implications, particularly on some specific neurosurgical disease conditions that were not generalized to the others, was mentioned ${ }^{17}$. Therefore, this retrospective study was performed to present the severity of illness by acknowledging the APACHE II score among neurosurgical ICU patients, to predict mortality reflecting APACHE II performance, and to evaluate the relationship of APACHE II score parameters as if they could estimate the length of hospital stay.

\section{Patients and Methods}

This study had been registered at the Thai Clinical Trials Registry with the identification number of TCTR 20150925001. Approval for the study (No. 10/2555) was received from the Prasat Neurological Institutional Ethics Committee (Chairman: Suchart Hanchaipiboonkul) on February 8, 2012, and written informed consent was obtained from all patients or legal relatives in case of unconsciousness. All patients admitted to neurosurgical ICU at Prasat Neurological Institute, Bangkok, between February 1 and July 31, 2011 were recruited. Demographics and the parameters indicating APACHE II score were collected within 30 minutes after admission by certified neurosurgical registrar nurses. The score calculation software was developed based on Microsoft Excel 2007 software (Seattle, WA, 2007) to convert those parameters, i.e. body temperature, mean arterial pressure, heart rate, respiratory rate, alveolar-arterial oxygen (A-a) gradient; if fractional inspired oxygen concentration is $\geq 0.5$, arterial oxygen tension $\left(\mathrm{PaO}_{2}\right)$; if fractional inspired oxygen concentration is $<0.5$, serum bicarbonate $\left(\mathrm{HCO}_{3}\right)$; if there is no arterial blood gas analysis, arterial $\mathrm{pH}$, serum sodium, serum potassium, creatinine, hematocrit, white blood cell count, Glasgow Coma Scale score, age and medical condition were entered into the APACHE II score, as shown in Figure $1^{4}$. The adjusted predicted risk of death (R) for each patient was calculated based on the patient's APACHE diagnosis, APACHE II score, and surgical status by using the APACHE II risk of death equation [ $\ln (\mathrm{R} / 1$ $\mathrm{R})=-3.517+($ APACHE II score $\mathrm{x} 0.146)+(0.603$, only if postoperative emergency surgery) + (diagnostic category weight, as indicated in listing of diagnostic categories leading to ICU admission) $]^{4}$. The length of stay and Glasgow Outcome Scale score were also recorded at unit discharge and hospital discharge. The observed death rate was compared with the risk-adjusted death prediction for the study population.

This retrospective study was performed within a 6-month period, expected to recruit 250 patients at least. The NQuery Advisor software version 6.0 (Boston, MA, 2005) was calculated to reassure the power of this study according to Park et al. ${ }^{3}$, which showed the adjusted predicted mortality rate in neurosurgical ICU. Finally, it was found that the power would increase to $99 \%$ if capable to detect the difference between the null hypothesis proportion of 0.38 and the alternative proportion of 0.25 , with the sample size of 228 , a single group t-test with a 0.05 two-sided significance level.

For demographic data, descriptive statistics was used and reported as mean, standard deviation (SD), 95\% confidence interval (95\% CI), number and percent. The area under the receiver operating characteristic curve (AUC) was analyzed, as well as the optimal cut point to demonstrate the capability of APACHE 


\begin{tabular}{|c|c|c|c|c|c|c|c|c|c|}
\hline \multirow{2}{*}{ Physiologic Variable } & \multicolumn{9}{|c|}{ Points } \\
\hline & +4 & +3 & +2 & +1 & 0 & +1 & +2 & +3 & +4 \\
\hline 1. Temperature $\left({ }^{\circ} \mathrm{C}\right)$ & $\geq 41$ & $39-40.9$ & & $38.5-38.9$ & $36-38.4$ & $34-35.9$ & $32-33.9$ & $30-31.9$ & $\leq 29.9$ \\
\hline $\begin{array}{l}\text { 2. Mean arterial pressure } \\
(\mathrm{mmHg})\end{array}$ & $\geq 160$ & $130-159$ & $110-129$ & & $70-109$ & & $50-69$ & & $\leq 49$ \\
\hline 3. Heart rate $(/ \mathrm{min})$ & $\geq 180$ & $140-179$ & $110-139$ & & $70-109$ & & $55-69$ & $40-54$ & $\leq 39$ \\
\hline 4. Respiratory rate (/min) & $\geq 50$ & $35-49$ & & $25-34$ & $12-24$ & $10-11$ & $6-9$ & & $\leq 5$ \\
\hline $\begin{array}{l}\text { 5. Oxygenation }(\mathrm{mmHg}) \\
\text { a. } \mathrm{A}-\mathrm{aDO}_{2} \text { if } \mathrm{FiO}_{2} \geq 0.5 \\
\text { b. } \mathrm{PaO}_{2} \text { if } \mathrm{FiO}_{2}<0.5\end{array}$ & 500 & $350-499$ & $200-349$ & & $\begin{array}{l}<200 \\
>70\end{array}$ & $61-70$ & & $55-60$ & $<55$ \\
\hline $\begin{array}{l}\text { 6. Acid-base balance } \\
\text { a. Arterial } \mathrm{pH} \\
\text { b. Serum } \mathrm{HCO}_{3}(\mathrm{mEq} / \mathrm{l}) \\
\text { if no arterial blood gas }\end{array}$ & $\begin{array}{l}\geq 7.7 \\
\geq 52\end{array}$ & $\begin{array}{l}7.6-7.69 \\
41-51.9\end{array}$ & & $\begin{array}{l}7.5-7.59 \\
32-40.9\end{array}$ & $\begin{array}{c}7.33-7.49 \\
22-31.9\end{array}$ & & $\begin{array}{c}7.25-7.32 \\
18-21.9\end{array}$ & \begin{tabular}{|c|}
$7.15-7.24$ \\
$15-17.9$
\end{tabular} & $\begin{array}{l}<7.15 \\
<15\end{array}$ \\
\hline 7. Sodium $(\mathrm{mEq} / \mathrm{l})$ & $\geq 180$ & $160-179$ & $155-159$ & $150-154$ & $130-149$ & & $120-129$ & $111-119$ & $\leq 110$ \\
\hline 8. Potassium $(\mathrm{mEq} / \mathrm{l})$ & $\geq 7$ & $6-6.9$ & & $5.5-5.9$ & $3.5-5.4$ & 3-3.4 & $2.5-2.9$ & & $<2.5$ \\
\hline 9. Creatinine $(\mathrm{mg} / \mathrm{dl})$ & $\geq 3.5$ & $2-3.4$ & $1.5-1.9$ & & $0.6-1.4$ & & $<0.6$ & & \\
\hline 10. Hematocirt (\%) & $\geq 60$ & & $50-59.9$ & $46-49.9$ & $30-45.9$ & & $20-29.9$ & & $<2.5$ \\
\hline $\begin{array}{l}\text { 11. White blood count } \\
\left(\times 1000 / \mathrm{mm}^{3}\right)\end{array}$ & $\geq 40$ & & $20-39.9$ & 15.19 .9 & $3-14.9$ & & $1-2.9$ & & $<1$ \\
\hline $\begin{array}{l}\text { 12. Glasgow Coma Score } \\
\text { (GCS) }\end{array}$ & & & & Score $=$ & 15 minus act & tual GCS & & & \\
\hline \multicolumn{10}{|c|}{ A. Total Acute Physiology Score (sum of 12 above points) } \\
\hline \multicolumn{10}{|c|}{ B. Age points (years) $\leq 44=0 ; 45$ to $54=2 ; 55$ to $64=3 ; 65$ to $74=5 ; \geq 75=6$} \\
\hline \multicolumn{10}{|c|}{ C. Chronic Health Points* } \\
\hline \multicolumn{10}{|c|}{ Total APACHE II Score (add together the points from A+B+C) } \\
\hline
\end{tabular}

* Chronic Health Points: If the patient has a history of severe organ system insufficiency or is immune-compromised as defined below, assign points as follows:

5 points for non-operative or emergency post-operative patients

2 points for elective post-operative patinets

Fig. 1. Summary variables and calculation methods for Acute Physiology and Chronic Health Evaluation (APACHE) II score.

II score to predict death rate. Pearson's correlation was conducted using the SPSS software version 16 (Markham, Ontario, Canada, 2007) to determine the correlation of APACHE II score and the length of stay. If the correlation is over 0.8 at $p$-value $<0.05$, the predictive property of APACHE II parameters and the length of stay are further analyzed with the general linear model. The values were expressed as mean difference and $95 \% \mathrm{CI}$.

\section{Results}

There were 276 patients admitted to the neurosurgical ICU, mean age \pm SD $47.94 \pm 15.39$ years. Of these,
246 (89.13\%) were elective cases and 30 (10.87\%) were emergency cases. Two hundred and fifty-eight (93.48\%) patients were transferred from the operating theater, 12 (4.35\%) from hospital ward, and six (2.17\%) from outside the hospital. Demographics and patient characteristics are shown in Table 1.

Arterial blood gas analyses were performed completely in all 276 patients. Only two in the cerebral tumor and two in cerebral vascular lesion categories had received high concentration of oxygen $\left(\mathrm{FiO}_{2}>0.5\right)$, showing a mean $\mathrm{A}$-a gradient of $178.85 \pm 67.49 \mathrm{~mm}$ $\mathrm{Hg}$. The incidence of acute renal failure and comorbidities indicating chronic health points, i.e. AIDS, hepatic failure, lymphoma, metastasis cancer, leukemia, 
Table 1. Demographics and patient characteristics

\begin{tabular}{|l|l|}
\hline Variable & Number (\%) \\
\hline Sex: Male & $120(43.5)$ \\
Diagnosis & $201(75.0)$ \\
- Cerebral tumor & $28(10.1)$ \\
- Cerebral aneurysm & $11(4.0)$ \\
- Spondylosis & $4(1.5)$ \\
- Spinal tumor & $26(9.4)$ \\
- Others & \\
Operation & $193(69.9)$ \\
- Craniotomy with lesion removal & $24(8.7)$ \\
- Craniotomy with clipping aneurysm & $15(5.4)$ \\
- Spinal surgery & $44(15.9)$ \\
- Others & \\
Reason for admission & $258(93.5)$ \\
- Major operation & $17(6.2)$ \\
- Neurologic problems & $1(0.4)$ \\
- Pulmonary problems &
\end{tabular}

immune compromise and cirrhosis were not identified. The APACHE II parameters are shown in Table 2.

There was no death at ICU discharge, while Glasgow Outcome Scale scores 2-5 (persistent vegetative state to good recovery) were recorded in one (0.36\%), 14 (5.07\%), 77 (27.90\%) and 184 (66.67\%) patients, respectively. At hospital discharge, 12 (4.35\%) patients died. Of the 264 (95.65\%) survivors, one
Table 2. Values of Acute Physiology and Chronic Health Evaluation (APACHE) II variables

\begin{tabular}{|l|l|l|}
\hline Variable & Number $(\%)$ & Mean \pm SD \\
\hline Temperature $\left({ }^{\circ} \mathrm{C}\right)$ & $276(100)$ & $36.47 \pm 0.77$ \\
$\mathrm{MAP}(\mathrm{mm} \mathrm{Hg})$ & $276(100)$ & $108.72 \pm 22.43$ \\
Heart rate $(/ \mathrm{min})$ & $276(100)$ & $82.21 \pm 16.66$ \\
$\mathrm{RR}(/ \mathrm{min})$ & $276(100)$ & $18.22 \pm 3.88$ \\
$\mathrm{PaO}(\mathrm{mm} \mathrm{Hg})$ & $276(100)$ & $200.74 \pm 86.63$ \\
$\mathrm{pH}$ & $276(100)$ & $7.39 \pm 0.07$ \\
Sodium $(\mathrm{mEq} / \mathrm{L})$ & $276(100)$ & $137.98 \pm 3.83$ \\
Potassium $(\mathrm{mEq} / \mathrm{L})$ & $276(100)$ & $3.78 \pm 0.43$ \\
Creatinine $(\mathrm{mg} / \mathrm{dL})$ & $276(100)$ & $0.81 \pm 0.33$ \\
Hematocrit $(\%)$ & $276(100)$ & $34.90 \pm 4.70$ \\
WBC count $\left(\mathrm{x} 10^{3} / \mu \mathrm{L}\right)$ & $276(100)$ & $14.10 \pm 5.65$ \\
$\mathrm{GCS}$ & $276(100)$ & $10.33 \pm 3.63$ \\
Age (years) & & $47.94 \pm 15.39$ \\
$\quad-\leq 44$ & $120(43.5)$ & \\
$-45-54$ & $62(22.5)$ & \\
$-55-64$ & $52(18.8)$ & \\
$-65-74$ & $26(9.4)$ & \\
$-\geq 75$ & $16(5.8)$ & \\
\hline
\end{tabular}

$\mathrm{MAP}=$ mean arterial pressure; $\mathrm{RR}=$ respiratory rate; $\mathrm{GCS}=$ Glasgow Coma Score

(0.36\%) had persistent vegetative state, seven (2.54\%) were conscious but disabled, 42 (15.22\%) were disabled but independent, and 214 (77.54\%) had good

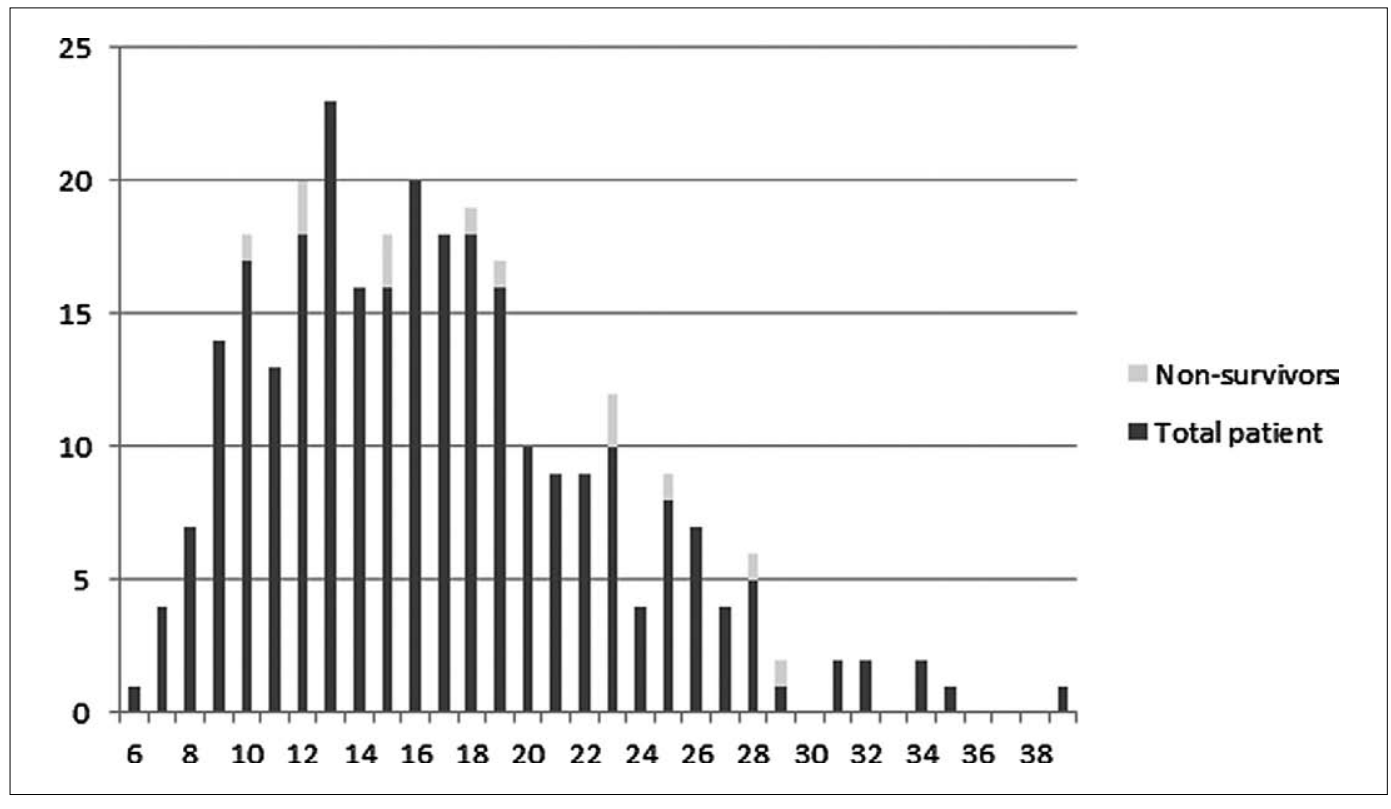

Fig. 2. Hospital mortality categorized by Acute Physiology and Chronic Health Evaluation (APACHE) II score. 
recovery and were capable to return to their way of life. The overall APACHE II score in survivors and non survivors was $16.56 \pm 5.95$ (95\% CI, 15.84-17.29) and $19.08 \pm 6.47(95 \% \mathrm{CI}, 15.40-22.76)$, while the calculated APACHE II adjusted predicted mortality was

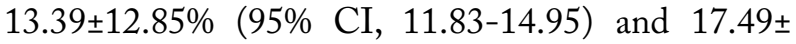
$13.51 \%$ (95\% CI, 9.81-25.17), respectively. The APACHE II score and hospital mortality are summarized in Figure 2.

The AUC of APACHE II score to hospital mortality was 0.62 (95\% CI, 0.44-0.79), as shown in Figure 3 . Finally, the optimal cut point of 18 would yield the sensitivity of $58.33 \%$ (95\% CI, 52.52-64.15) and specificity of $61.36 \%$ (95\% CI, 55.62-67.11).

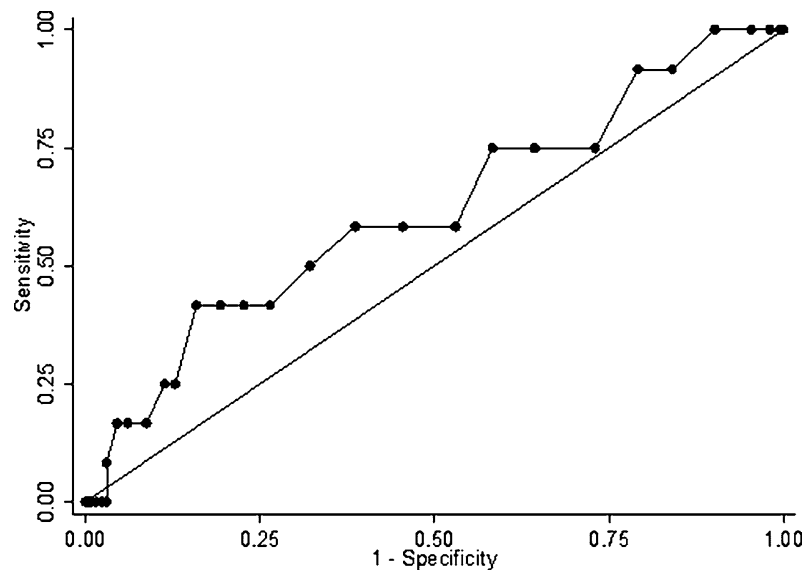

Fig. 3. The receiver operating characteristic curve of the Acute Physiology and Chronic Health Evaluation (APACHE) II score.

Seventeen patients had total length of hospital stay of over 114 days. The mean \pm SD and median (minmax) for total length of hospital stay were $32.37 \pm 65.57$ days and 12 (2-535) days, while the mean \pm SD and median (min-max) for the length of ICU stay were $2.55 \pm 2.51$ days and 2 (1-25) days, respectively.

The correlation of APACHE II score with the length of ICU stay $\left(r^{2}=0.12\right.$ with $95 \%$ CI $0.00-0.23$; $\mathrm{p}=0.036)$ and length of hospital stay $\left(\mathrm{r}^{2}=0.07\right.$ with $95 \%$ CI, 0.05-0.19; $\mathrm{p}=0.24$ ) was nonsignificant.

\section{Discussion}

This study demonstrated the severity of patient conditions in neurosurgical ICU in terms of APACHE II score, which probably reflects the spectrum of a ter- tiary referral neurosurgical center. Nevertheless, the mortality and length of hospital stay prediction was not achieved by APACHE II model.

For the performance of mortality prediction, the APACHE II scale has been validated and accepted in many settings of general ICU, with the AUC varying from 0.74 to $0.86^{17-21}$. The risk-adjusted formula to predict mortality estimated from APACHE II score is a remarkable advantage ${ }^{18,19}$. The diagnostic category weight variables, e.g., the causes of respiratory failure, the causes of cardiovascular failure, the major vital organ surgeries leading to ICU admission post-surgery, type of surgery, etc., were included ${ }^{4,22}$. However, the adjusted predicted values were not related to the observed mortality and could not discriminate between survivors and non-survivors in neurosurgical ICU. The possibility of monitoring modality, the effectiveness of multidisciplinary team, therapeutic preference and patient unique characteristics were considered, in particular patient distinctive nature, disease specific pathology, and severity of illness ${ }^{23,24}$.

Besides the property of APACHE II score in mortality prediction, determining the length of hospitalization was also expected. This study showed a nonsignificant correlation between the scores and the length of hospital stay. Interestingly, even the length of ICU stay was longer than in an earlier study but when compared to general ICU, it was still shorter ${ }^{25}$. This result is in contrast to the study by Rubiano et al., who report that the length of stay in teaching hospitals is longer because they need more time to investigate and take care specifically ${ }^{26}$.

The practical reason that was different from the others was the primary patient condition. Most of the patients admitted to neurological ICU in this setting were healthy or were partially treated before their transfer. Ninety-three percent of the patients were admitted with the criterion of postoperative major neurosurgery without any other complications. In fact, the term 'High Dependency Care Unit' may be used properly instead of the term 'Intensive Care Unit' in these circumstances ${ }^{27}$. Moreover, this unit has been organized as an open intensive care system. The responsible physician is a neurosurgeon appointed on the bed quota basis, which resulted in a lower and wider range of APACHE II scores (6-39 score of 0-67 total score).

Our study had several limitations. Firstly, we used an ICU to take care of postoperative patients that were 
healthy and most of them did not have any other complications. Despite this, the APACHE II score is less likely to represent the severity of the real situation. We would recommend re-estimation of the patients according to the admission criteria if applied to a national sample. Secondly, our hospital sample had a limited number of performance outliers because it is a tertiary referral healthcare center. There were a few cases of traumatic brain injury or emergency situation. A larger sample of cases is needed to draw more reliable conclusions in these circumstances. Thirdly, there was a limitation of the assessment frequency, as even the criteria of APACHE II evaluation were recommended to be measured once within 24 hours of admission but the estimated accuracy would be increased if the assessment could have been performed periodically.

In conclusion, the mean APACHE II score in neurosurgical ICU patients was $16.67 \pm 5.99$ (95\% CI, 15.96-17.38). The calculated adjusted predicted mortality was $13.57 \pm 12.88 \%$ (95\% CI, 12.04-15.09), while the hospital-discharge mortality was only $4.35 \%$. We found that the mortality predictive performance of APACHE II score was not precise. Nevertheless, these results can provide general informative data to the benefit of setting standard clinical indicators individually and initiate liberal study of the mortality predictor in these critical patients in the future.

\section{References}

1. Kiphuth IC, Schellinger PD, Kohrmann M, Bardutzky J, Lucking H, Kloska S, et al. Predictors for good functional outcome after neurocritical care. Crit Care. 2010;14:R136.

2. Rodriguez Villar S, Barrientos Yuste RM. Long-term admission to the intensive care unit: a cost-benefit analysis. Rev Esp Anestesiol Reanim. 2014;61:489-96. http://dx.doi.org/ 10.1016/j.redar.2014.02.008.

3. Park SK, Chun HJ, Kim DW, Im TH, Hong HJ, Yi HJ. Acute Physiology and Chronic Health Evaluation II and Simplified Acute Physiology Score II in predicting hospital mortality of neurosurgical intensive care unit patients. J Korean Med Sci. 2009;24:420-6.http://dx.doi.org/10.3346/jkms.2009.24.3.420.

4. Knaus WA, Draper EA, Wagner DP, Zimmerman JE. APACHE II: a severity of disease classification system. Crit Care Med. 1985;13:818-29.

5. Moon BH, Park SK, Jang DK, Jang KS, Kim JT, Han YM. Use of APACHE II and SAPS II to predict mortality for hemorrhagic and ischemic stroke patients. J Clin Neurosci. 2014; 22:111-5. http://dx.doi.org/10.1016/j.jocn.2014.05.031.
6. Beck DH, Taylor BL, Millar B, Smith GB. Prediction of outcome from intensive care: a prospective cohort study comparing Acute Physiology and Chronic Health Evaluation II and III prognostic systems in a United Kingdom intensive care unit. Crit Care Med. 1997;25:9-15.

7. Markgraf R, Deutschinoff G, Pientka L, Scholten T. Comparison of Acute Physiology And Chronic Health Evaluations II and III and Simplified Acute Physiology Score II: a prospective cohort study evaluating these methods to predict outcome in a German interdisciplinary intensive care unit. Crit Care Med. 2000;28:26-33.

8. Ting HW, Chen MS, Hsieh YC, Chan CL. Good mortality prediction by Glasgow Coma Scale for neurosurgical patients. J Chin Med Assoc. 2010;73:139-43. http://dx.doi.org/10.1016/ S1726-4901(10)70028-9.

9. Dalgic A, Ergungor FM, Becan T, Elhan A, Okay O, Yuksel BC. The revised Acute Physiology and Chronic Health Evaluation System (APACHE II) is more effective than the Glasgow Coma Scale for prediction of mortality in head-injured patients with systemic trauma. Ulus Travma Acil Cerrahi Derg. 2009;15:453-8.

10. Assembly MECC. APACHE IV Calculator 2009 [cited 2011 October 29]. Available from: http://www.mecriticalcare.net/ icu_scores/apacheIV.php.

11. Salluh JI, Soares M. ICU severity of illness scores. APACHE, SAPS and MPM. Curr Opin Crit Care. 2014;20:557-65. http://dx.doi.org/10.1097/MCC.0000000000000135.

12. Mann SL, Marshall MR, Woodford BJ, Holt A, Williams AB. Predictive performance of Acute Physiological and Chronic Health Evaluation releases II to IV: a single New Zealand centre experience. Anaesth Intensive Care. 2012;40:479-89.

13. Wetzel RC, Sachedeva R, Rice TB. Are all ICUs the same? Paediatr Anaesth. 2011;21:787-93. http://dx.doi.org/10.1111 /j.1460-9592.2011.03595.

14. Markandaya M, Thomas KP, Jahromi B, Koenig M, Lockwood $\mathrm{AH}$, Nyquist PA, et al. The role of neurocritical care: a brief report on the survey results of neurosciences and critical care specialists. Neurocrit Care. 2012;16:72-81. http://dx.doi.org/ 10.1007/s12028-011-9628-2.

15. Nuttall D, Parkin D, Devlin N. Inter-provider comparison of patient-reported outcomes: developing an adjustment to account for differences in patient case mix. Health Economics. 2015;24:41-54. http://dx.doi.org/10.1002/hec.2999.

16. Mirski MA, Chang CW, Cowan R. Impact of a neuroscience intensive care unit on neurosurgical patient outcomes and cost of care: evidence-based support for an intensivist-directed specialty ICU model of care. J Neurosurg Anesthesiol. 2001;13: 83-92.

17. Su Y, Wang M, Liu Y, Ye H, Gao D, Chen W, et al. Module modified Acute Physiology and Chronic Health Evaluation II: predicting the mortality of neuro-critical disease. Neurol Res. 2014;36:1099-105.

http://dx.doi.org/10.1179/1743132814Y.0000000395. 
18. Qiao Q, Lu G, Li M, Shen Y, Xu D. Prediction of outcome in critically ill elderly patients using APACHE II and SOFA scores. J Int Med Res. 2012;40:1114-21.

19. Zali AR, Seddighi AS, Seddighi A, Ashrafi F. Comparison of the Acute Physiology and Chronic Health Evaluation score (APACHE) II with GCS in predicting hospital mortality of neurosurgical intensive care unit patients. Glob J Health Sci. 2012;4:179-84. http://dx.doi.org/10.5539/gjhs.v4n3p179.

20. Delibegovic S, Markovic D, Hodzic S. APACHE II scoring system is superior in the prediction of the outcome in critically ill patients with perforative peritonitis. Med Arh. 2011;65: $82-5$.

21. Fadaizadeh L, Tamadon R, Saeedfar K, Jamaati HR. Performance assessment of Acute Physiology and Chronic Health Evaluation II and Simplified Acute Physiology Score II in a referral respiratory intensive care unit in Iran. Acta Anaesthesiol Taiwan. 2012;50:59-62. http://dx.doi.org/10.1016/j.aat.2012.05.004.

22. Al Tehewy M, El Houssinie M, El Ezz NA, Abdelkhalik M, El Damaty S. Developing severity adjusted quality measures for intensive care units. Int J Health Care Qual Assur. 2010;23: 277-86.
23. Kapoustina O, Echegaray-Benites C, Gelinas C. Fluctuations in vital signs and behavioural responses of brain surgery patients in the intensive care unit: are they valid indicators of pain? J Adv Nurs. 2014;70:2562-76.

http://dx.doi.org/10.1111/jan.12409.

24. Sadaka F, Cytron MA, Fowler K, Javaux VM, O’Brien J. A model for identifying patients who may not need neurologic intensive care unit admission: resource utilization study. J Intensive Care Med. 2016;31(3):193-7. http://dx.doi.org/10.1177/0885066614530952.

25. Zacharia BE, Vaughan KA, Bruce SS, Grobelny BT, Narula R, Khandji J, et al. Epidemiological trends in the neurological intensive care unit from 2000 to 2008. J Clin Neurosci. 2012; 19:1668-72. http://dx.doi.org/10.1016/j.jocn.2012.04.011.

26. Rubiano S, Gil F, Celis-Rodriguez E, Oliveros H, Carrasquilla G. Critical care in Colombia: differences between teaching and nonteaching intensive care units. A prospective cohort observational study. J Crit Care. 2011;27:104 e9-17. http://dx.doi. org/10.1016/j.jcrc.2011.03.006.

27. Gould A, Ho KM, Dobb G. Risk factors and outcomes of high-dependency patients requiring intensive care unit admission: a nested case-control study. Anaesth Intensive Care. 2011;38:855-61.

Sažetak

\title{
SUSTAV APACHE II. KAO KLINIČKI PREDIKTOR U NEUROKIRURŠKOJ JEDINICI INTENZIVNOG LIJEČENJA
}

\author{
P. Akavipat, J. Thinkhamrop, B. Thinkhamrop i W. Sriraj
}

Sustav APACHE II. odobren je kao mjerilo i prediktor smrtnosti, no samo se nekoliko članaka bavi njegovom primjenom kod neurokirurških bolesnika. Stoga smo proveli ovo istraživanje kako bismo potvrdili ovaj sustav i njegovu sposobnost predviđanja bolničke smrtnosti u referentnoj tercijarnoj neurokirurškoj jedinici intenzivnog liječenja (JIL). U istraživanje su bili uključeni svi bolesnici primljeni u neurokiruršku JIL od 1. veljače do 31. srpnja 2011. godine. Prikupljeni su podaci koji se odnose na parametre sustava APACHE II. Izračunat je prilagođeni rizik smrti i uspoređen sa zabilježenom stopom smrtnosti. U analizi je primijenjena deskriptivna statistika uključujući ROC. Rezultati su pokazali da je primljeno 276 bolesnika. Zbir APACHE II. bio je 16,56 (95\% CI, 15,84-17,29) za preživjele i 19,08 (95\% CI, 15,40-22,76) za umrle, dok je prilagođena predviđena stopa smrtnosti bila 13,39\% (95\% CI, 11,83-14,95) odnosno 17,49\% (95\% CI, 9,81-25,17). Zabilježena stopa smrtnosti bila je samo 4,35\%. Područje ispod ROC zbira APACHE II. za bolničku smrtnost iznosila je 0,62 (95\% CI, 0,44-0,79). U zaključku, ne samo da je zbir APACHE II. pokazao nisku težinu kod neurokirurških bolesnika, nego je i njegov rezultat u predviđanju bolničke smrtnosti bio nezadovoljavajući. Treba provesti daljnja istraživanja prediktora smrtnosti kod ovih kritičnih bolesnika.

Ključne riječi: APACHE; Bolnička smrtnost; Dužina hospitalizacije; Stupanj težine bolesti; Jedinice intenzivne skrbi 